\title{
IODOMETRIC DETERMINATION OF COPPER AND IRON IN ONE SOLUTION
}

\author{
J. Agterdenbos and E. J. v. Tellingen \\ Analytical Chemistry Laboratory, State University, Utrecht, Holland
}

(Received 8 February 1961. Accepted 15 February 1961)

\begin{abstract}
Summary-Copper ${ }^{\mathrm{II}}$ and iron $^{\mathrm{III}}$ may be titrated iodometrically in a single solution. Copper is titrated first, iron being masked with fluoride. After the end-point is reached, aluminium chloride is added to de-mask the iron, which is titrated after some minutes. Good results are obtained.
\end{abstract}

\section{INTRODUCTION}

THE iodometric determination of copper ${ }^{\mathrm{II}}$ in the presence of iron ${ }^{\mathrm{III}}$ is usually performed in weakly acid medium. Iron is masked by fluoride. Just before the end-point, thiocyanate is often added, to liberate iodine, which is adsorbed on the CuI-precipitate. If no thiocyanate is added, low results are obtained. ${ }^{1}$ The reaction between iron ${ }^{1 I I}$ and iodide is performed at $\mathrm{pH} \sim 1$. The reaction is rather slow, therefore 15-30 minutes should be allowed before titrating. Alternatively some Cul suspension may be added as a catalyst, when the titration may be performed immediately.

Two papers ${ }^{2.3}$ are known to the present authors, dealing with the iodometric titration of both ions in the same solution. In both papers iron is masked with fluoride. After the copper end-point is reached, the solution is acidified, and boric acid is added to de-mask the iron. The iron is titrated as described above. In the first paper, that of Lang and Reifer, ${ }^{2}$ two points should be noted: (1) no thiocyanate was added, and (2) if small quantities of copper were present, not enough Cul was formed for the catalytic action. Therefore a known amount of copper was added before the titration.

The second paper by Kinnunen and Wennerstrand, ${ }^{3}$ deals with the analysis of copper-base alloys, in which the iron-content is low. It is stressed that no thiocyanate should be used in the copper titration if iron is to be determined afterwards.

In both methods large amounts of ammonium salts are present before the titration begins. In the first, 5-10 $\mathrm{g}$ of $\left(\mathrm{NH}_{4}\right)_{2} \mathrm{SO}_{4}$ are added; in the second the excess of $\mathrm{HNO}_{3}$, used to dissolve the alloy, is neutralised with $\mathrm{NH}_{4} \mathrm{OH}$.

\section{EXPERIMENTAL}

The use of boric acid as demasking agent

The experiments of Lang and Reifer ${ }^{2}$ were repeated. About 1 mmole of copper and 1.2 mmole of iron were present. It was found, however, that poor results were obtained for iron unless, after dissolution of the boric acid, the titration of iron was delayed for about $1 \mathrm{hr}$. Presumably this time is necessary for complete de-masking of the iron.

Several changes in the experimental conditions were tried to accelerate the de-masking reaction. They included addition of thiocyanate at several stages of the procedure, replacement of ammonium sulphate by other salts, or omission of this salt (sulphate ion has been reported to slow down the reaction between iron ${ }^{\mathrm{II}}$ and iodides). However, no improvement was found.

In an attempt to reproduce the work of Kinnunen and Wennerstrand, ${ }^{3}$ some experiments were performed in which the quantity of iron was about 0.25 mmole. Results for copper were slightly low, because no thiocyanate was used. For iron, results were satisfactory, though it was necessary 
to wait a few minutes after boric acid was added, before the iron titration was started. For larger amounts of iron, however, poor results were obtained with this procedure.

Another de-masking agent was therefore sought. The stability constants compiled by Bjerrum et $a l .{ }^{5}$ showed that the use of aluminium and thorium might lead to success. Aluminium was selected for further investigation.

TABLE 1.-TITRATION OF COPPER-IRON MIXTURES (Second series of experiments)

\begin{tabular}{|c|c|c|c|c|c|c|}
\hline \multirow{2}{*}{$\begin{array}{c}\text { No. } \\
\text { of experiment }\end{array}$} & \multicolumn{3}{|c|}{$\begin{array}{l}0.1 \mathrm{~N} \text { thiosulphate, } \\
\text { for copper, } m l\end{array}$} & \multicolumn{3}{|c|}{$\begin{array}{l}0 \cdot 1 \mathrm{~N} \text { thiosulphate, } \\
\text { for iron, } m l\end{array}$} \\
\hline & used & calc. & diff. & used & calc. & diff. \\
\hline 1 & 6.42 & $6 \cdot 43$ & +0.01 & $31 \cdot 20$ & $31 \cdot 21$ & -0.01 \\
\hline 2 & 6.43 & 6.43 & 0.00 & $31 \cdot 27$ & $31 \cdot 21$ & +0.07 \\
\hline 3 & $12 \cdot 90$ & $12 \cdot 94$ & -0.04 & $26 \cdot 02$ & $26 \cdot 03$ & -0.01 \\
\hline 4 & 12.93 & 12.94 & -0.01 & $26 \cdot 00$ & 26.03 & -0.03 \\
\hline 5 & $19 \cdot 40$ & 19.37 & +0.03 & $20 \cdot 80$ & 20.82 & -0.02 \\
\hline 6 & $19 \cdot 39$ & $19 \cdot 37$ & +0.02 & $20 \cdot 84$ & $20 \cdot 82$ & +0.02 \\
\hline 7 & 25.90 & 25.88 & -0.02 & 15.55 & 15.59 & -0.04 \\
\hline 8 & $25 \cdot 87$ & 25.88 & $-0,01$ & $15 \cdot 59$ & $15 \cdot 59$ & $0 \cdot 00$ \\
\hline 9 & $32 \cdot 31$ & $32 \cdot 33$ & -0.02 & $10 \cdot 50$ & $10 \cdot 41$ & +0.09 \\
\hline 10 & $32 \cdot 33$ & $32 \cdot 33$ & 0.00 & $10 \cdot 42$ & $10 \cdot 41$ & +0.01 \\
\hline 11 & $38 \cdot 75$ & $38 \cdot 76$ & -0.01 & $5 \cdot 24$ & $5 \cdot 18$ & +0.06 \\
\hline \multirow[t]{2}{*}{12} & $38 \cdot 77$ & $38 \cdot 76$ & +0.01 & $5 \cdot 24$ & $5 \cdot 18$ & +0.06 \\
\hline & \multicolumn{3}{|c|}{ Mean difference: $0.00 \mathrm{ml}$} & \multicolumn{3}{|c|}{$\begin{array}{c}\text { Mean difference: } \\
\quad+0.017 \mathrm{ml}\end{array}$} \\
\hline
\end{tabular}

The use of aluminium as a demasking agent

Stock solutions of copper ${ }^{\mathrm{II}}$ and iron ${ }^{\mathrm{III}}$ were prepared by dissolving pure copper in nitric acid and by dissolving iron ${ }^{\mathrm{III}}$ oxide p.a. in hydrochloric acid. The concentrations were checked iodometrically and (for copper only) electrolytically, and were $268.93 \mathrm{mg}$ of copper and $150.8 \mathrm{mg}$ of iron ${ }^{\mathrm{III}}$ oxide in $25 \mathrm{ml}$ of stock solution.

Procedure: Twenty-five $\mathrm{ml}$ of each of the stock-solutions were transferred to a flask, and neutralised with $\mathrm{NH}_{4} \mathrm{OH} ; 800 \mathrm{mg}$ of $\mathrm{KHF}_{2}$ were added, and, after the precipitate had dissolved, $2-3 \mathrm{~g}$ of $\mathrm{KI}$. The titration was performed with $0.1 \mathrm{~N}$ thiosulphate solution, standardised with $\mathrm{KIO}_{3}$. After the starch end-point was reached, $10 \mathrm{ml}$ of $10 \% \mathrm{KCNS}$ solution were added and the titration was completed. Then $25 \mathrm{ml}$ of a solution of $\mathrm{AlCl}_{3}$, containing $2.2 \mathrm{~g}$ of Al, were added. There was sufficient free $\mathrm{HCl}$ in the $\mathrm{AlCl}_{3}$ solution to give $\mathrm{pH} \sim 1$. Some $\mathrm{NaHCO}_{3}$ was added to eliminate the influence of oxygen, and the mixture was shaken for some min and titrated again with thiosulphate solution.

For copper, from seven experiments, the mean value, standard deviation and confidence limits $(\alpha=0.05)$ were found to be $269.04 \mathrm{mg}, 0.06 \%(=016 \mathrm{mg})$ and $268.89-269.18 \mathrm{mg}$. For iron these values were $150.5 \mathrm{mg}, 0.2 \%(=0.3 \mathrm{mg})$ and $150 \cdot 2-150 \cdot 8 \mathrm{mg}$.

A second series of experiments was performed in order to investigate the influence of the amounts of copper and iron present on the accuracy of the analysis. Some differences in the conditions, which are not believed to have affected the results, were: (1) $\mathrm{NH}_{4} \mathrm{HF}$ was used instead of $\mathrm{KHF}_{2}$. (2) Because in some of the experiments much more iron was present than in the first series, $2 \mathrm{~g}$ of the masking agent were added. (3) $40 \mathrm{ml}$ of an $\mathrm{AICl}_{3}$ solution containing $1.6 \mathrm{~g}$ of Al were used, and as this solution was only weakly acid, $10 \mathrm{ml}$ of $5 \mathrm{~N} \mathrm{H}_{2} \mathrm{SO}_{4}$ were added. (4) The iron solution was prepared from $\mathrm{Fe}\left(\mathrm{NO}_{3}\right)_{3}$ and standardised against thiosulphate. (5) The amount of $\mathrm{NH}_{4} \mathrm{OH}$ necessary to neutralise the copper-iron solution varied with the amount of the metals; the $\mathrm{NH}_{4}$-solution was added until the blue colour of the copper-ammine complex was just formed. Results of the second series of experiments are given in Table I. 


\section{DISCUSSION}

As might be expected, results for copper are very good in both series of experiments. For iron, the results in the first series seem quite good, although there may be a slight systematic negative error.

The results in the second series seem slightly too high for small quantities of iron. This was confirmed by duplicating experiments 11 and 12 . These results, were slightly too high by 0.04 and $0.06 \mathrm{ml}$ respectively. A blank value of $0.02-0.03 \mathrm{ml}$ was found in some experiments, giving a partial explanation of the high results. No further investigations were carried out to eliminate the discrepancy.

From all the experiments, it may be concluded that results for copper are very good. For large amounts of iron, results are good. For small amounts of iron the results seem slightly high, but the error is not more than about $0.5 \%$ if a blank is subtracted.

Acknowledgement-The authors wish to express their thanks to P. J. Elberse for experimental help.

Zusammenfassung-Kupfer(II) und Eisen(III) werden hintereinander in einer Lösung jodometrisch titriert. Bei der Kupfertitration wird Eisen mit Fluorid maskiert. Nachdem wird Eisen mit Aluminium demaskiert und nach einigen Minuten ebenfalls jodometrisch titriert. Die Ergebnisse sind gut.

Résumé-Le cuivre(II) et le fer(III) sont titrés l'un après l'autre dans une seule solution. D'abord on ajoute du iodure et du fluorure et en milieu peu acide le fer est masqué par le fluoride et le iode, libéré par la réaction avec le cuivre, et titré avec le thiosulphate. Après le titrage on ajoute de l'aluminium pour libérer le fer de son complex fiuoride, et après quelques minutes le titrage du fer est effectué en milieu acide par le thiosulphate. Les résultats sont bons.

\section{REFERENCES}

${ }^{I}$ E. W. Hammock and E. H. Swift, Analyt. Chem., 1949, 21, 975.

${ }^{2}$ R. Lang and J. Reifer, Z. analyt. chem., 1933, 93, 161.

3 J. Kinnunen and B. Wennerstrand, Metallurgia, 1954, 50, 149.

I. M. Kolthoff and R. Belcher, Volumetric Analysis. Interscience Publishers Ltd, London 1957. Vol. III, p. 342.

${ }^{5}$ J. Bjerrum, G. Schwarzenbach and L. G. Sillen, Stability Constants. The Chemical Society, London 1958. Part II, p. 88. 